TI 2017-087/VIII

Tinbergen Institute Discussion Paper

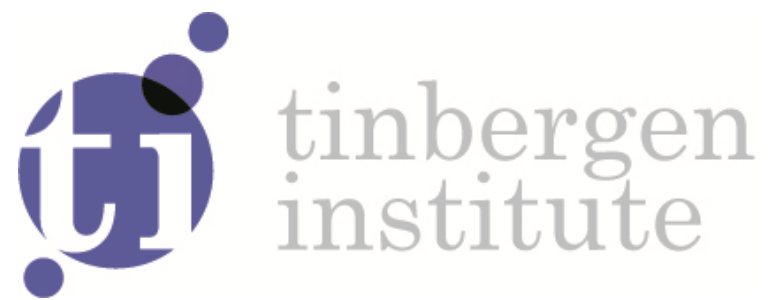

\title{
Assessing Electronic Service Delivery in Municipalities
}

Tjerk Budding ${ }^{1}$

Bram Faber ${ }^{2}$

Raymond (R.H.J.M.) Gradus ${ }^{3}$

1: School of Business and Economics, Vrije Universiteit Amsterdam

2: School of Business and Economics, Vrije Universiteit Amsterdam

3: School of Business and Economics, Vrije Universiteit Amsterdam; Tinbergen Institute, The Netherlands 
Tinbergen Institute is the graduate school and research institute in economics of Erasmus University Rotterdam, the University of Amsterdam and VU University Amsterdam.

Contact: discussionpapers@tinbergen.nl

More TI discussion papers can be downloaded at the Tinbergen Site

Tinbergen Institute has two locations:

Tinbergen Institute Amsterdam

Gustav Mahlerplein 117

1082 MS Amsterdam

The Netherlands

Tel.: +31(0)20 5984580

Tinbergen Institute Rotterdam

Burg. Oudlaan 50

3062 PA Rotterdam

The Netherlands

Tel.: +31(0)10408 8900 


\title{
Assessing Electronic Service De- livery in Municipalities: Determinants and financial consequences of $\mathbf{E}$ - government implementation
}

\author{
Tjerk Budding ${ }^{1}$, Bram Faber ${ }^{2}$ and Raymond Gradus ${ }^{3}$
}

\begin{abstract}
In the Netherlands, electronic service delivery has become an important issue in many municipalities. Using the Internet for service delivery is seen as an important element of egovernment. Based on 2014-2016 panel-data of ICT service delivery for all Dutch municipalities, we show that there is a large variety among the municipalities in the extent to which they offer their service delivery digitally. We explore the factors that may explain the differences among the municipalities. Some trends can be discerned, most notably the strong relationship of e-government adoption with demographic characteristics, such as population, population density and both older age and younger age groups. Remarkably, we did not find an influence of education and income. Finally, we did not observe a relation between municipal allocated costs and level of e-maturity, hereby leaving the question open if and how e-government can lead to cost reductions.
\end{abstract}

KEYWORDS: e-government, municipalities, service delivery, local government, cost of services, empirical study

\section{Introduction}

E-government has been heralded as one of the reforms to promote efficiency and responsiveness in government service delivery (Dunleavy et al. 2005). The development of e-government, which initially arose in the 1990s and manifestoing in the course of the 2000s, is primarily driven by the rationale of new public management (Cordella and Bonina 2012).

Two important implications can be discerned in the general discussion of e-government:

(1) it has an impact on the efficiency of internal processes, and

(2) it transforms the relationship between government and society.

The definitions and usage of the term 'e-government' are not clear-cut (Yildiz 2007): it is a concept that is defined by its implications, rather than by technologies or activities deployed to reach

\footnotetext{
${ }^{1}$ School of Business and Economics, Vrije Universiteit Amsterdam, email: g.budding@ vu.nl; corresponding author.

${ }^{2}$ School of Business and Economics, Vrije Universiteit Amsterdam, email: a.s.c.faber@vu.nl.

${ }^{3}$ School of Business and Economics, Vrije Universiteit Amsterdam, and Tinbergen Institute, email:

r.h.j.m.gradus@vu.nl.
} 
them. As such, e-government is widely researched, for all sorts of different contexts. As much as has been written in this field, it should be noticed that descriptive and qualitative studies are overrepresented (Rodríguez Bolívar, Alcaide Muñoz, and López 2016). Next to this, up to date only a few articles were found that address the issue of e-government adoption: the degree to which a government is inclined to adapt ICT infrastructure. The scarce writing on e-government adoption is especially surprising when looking at the Dutch context, as this provides a more or less ideal setting for quantitative research on this topic. Three major arguments can be given for researching e-government adoption in Dutch local government: (1) the central government to a large extent determines what tasks are to be executed by municipalities, but the latter are free to decide how they are organised; (2) Internet access in almost all municipalities is fast and reliable; and (3) not only are e-government adoption data made available periodically, but detailed municipal budgets are also well-documented. For this paper we are interested in the factors that could explain the impact of e-government on municipal service delivery. As mentioned before, up to date hardly any research of e-government adoption has been undertaken by means of quantitative analysis of empirical data, and the relation of e-government adoption with other variables. This paper tries to fill this gap, exploring the links between e-government adoption, demographic and socioeconomic characteristics and municipal costs.

The structure of this paper is as follows. After a review of relevant literature, we start out with an assessment of the relationship between the adoption of e-government and a selection of demographic and socioeconomic variables. Consequently we will look if there is a relationship between the degree of e-government adoption and specific cost items: does a thorough adoption of e-government lead to lower or higher costs?

\section{Literature review}

Ever since the early 2000s the importance of Internet took a rapid growth, and evolved into the centrepiece of governmental service delivery. There is a substantial body of literature addressing e-government and its emergence in public administration. Rodríguez Bolívar, Alcaide Muñoz, and López (2016) discern features and functionalities of articles published in this field. In their meta-analysis they show a continuous growth in the output of papers concerned with egovernment development and adoption in the period between 2000 and 2012. Following Carter and Belanger (2005) they discern three significant e-government approaches: (1) studies mainly considered with questions of accountability due to ICT-developments, (2) studies that investigate increased (or decreased) transparency for citizens, and (3) studies that evaluate questions of efficiency gains (or losses) through government usage of ICT.

A guiding principle in the context of service delivery is that of dividing and modelling egovernment evolution into sequential steps or 'stages of growth'-models (Valdés et al. 2011). These stages are often defined in terms of 'maturity', as is habitual in various other disciplines such as business economics. Layne and Lee (2001) were the first to formulate four stages of ICT-growth within government, primarily concerned with functionality and capability, gradually moving from absence of ICT towards 'horizontal integration', the idea that systems would be fully integrated across different functions, leading up to the public body as a 'real one stop shop for citizens' - related to the notion of a 'joined-up government' (Pollitt 2003). The stages concept of governmental ICT-usage has been adapted frequently, sometimes shifting the focus towards other aspects such as customer-centricity (Andersen and Henriksen 2006) and interoperability (Gottschalk 2009). 
There is some literature that addresses the factors exerting influence on e-government. Manoharan (2013), in his analysis of the progress of e-government adoption in counties in the United States, formulated that a constellation of factors (socioeconomic, institutional and contextual) were determinants of a greater extent of e-government adoption for local government. Nasi, Frosini, and Cristofoli (2011) moreover found that especially organisational factors and not so much environmental factors play a role in the adoption of e-government.

However, there is a discrepancy between the amount of qualitative and quantitative analysis that has been done on the subject of e-government adoption factors. In their meta-analysis odríguez Bolívar, Alcaide Muñoz, and López (2016) observed that a majority of the papers written on e-government were qualitative studies; especially case studies appear to be voluminous. They also found that many papers were descriptive, and did not build on earlier theories. For that reason they call for a more intensive deployment of quantitative research in the field.

\section{Assessing e-government in the context of Dutch local government}

After this overview of research on e-government, it makes sense to have a closer look at the Dutch local context. The Netherlands has three layers of government (central, province and municipalities). Municipalities in the Netherlands form the most visible layer of government. They perform tasks such as social assistance, physical planning, garbage and recyclables collection, and the issuance of passports and driver licences. For this reason it is evident that public service delivery towards citizens and businesses is largely concentrated around the municipalities. The Dutch central government has prescribed a large number of tasks that have to be performed by the local layer of government, but it is to a large extent at the municipalities' discretion how they wish to perform these tasks. This allows for a great variety of public policy, which is adapted and tailored to the local context.

According to a survey $95 \%$ of Dutch inhabitants have access to (high-speed) Internet (Statistics Netherlands, 2012). This puts the Netherlands among the countries with the highest Internet penetration in Europe. Additionally, the Netherlands recently has been ranked fourth in an EUassessment of e-government adoption by member states (European Commission 2017).

In the 2013-2017 coalition agreement of the Dutch central government, e-government is spearheaded as an important theme. In 2013 the responsible minister declared that citizens and business should be offered the opportunity to consume government services via Internet in 2017 at the latest (Interior Ministry 2013). ${ }^{i}$ As local governments are charged with the majority of direct service delivery, a large share of responsibility for the achievement of this objective lies with municipalities. Part of this is a periodical assessment, commissioned by the Ministry of Internal Affairs and Kingdom Relations and executed by Deloitte, of the 'e-maturity' ('digitale volwassenheid') of every Dutch municipality. For our analysis we explored the data used for this report.

\section{Data and method}

For the present paper we are interested in looking at the factors determining the extent of egovernment adoption in the Dutch context. On the basis of this question we formulate our hypotheses. In the reports used, the measure of e-government adoption is called 'e-maturity', and is specifically related to the extent to which a municipality offers a range of services through the Internet. In the report e-maturity is measured for each separate municipality as the weighted average of the total products it offers digitally - that is, through its website. Examples of products include the issuing of passports and applications for a parking license. Each separate product is given a score for its degree of e-maturity. Four percentage-termed stages are formulated, deter- 
mining the extent to which a municipal product is offered along a digital route (See Table 1). In this article, we follow Deloitte's definition.

Table 1. Stages of e-maturity of municipal products

\begin{tabular}{lc}
\hline Description & E-maturity score \\
\hline 1. Not digital, only information & $0 \%$ \\
2. Possibility to download, but requires printing (fill out manually) & $33 \%$ \\
3. Possibility to download, fill out digitally and send to municipality & $66 \%$ \\
4. In a digital portal, citizens can login with their Dutch citizen ser- & $100 \%$ \\
\hline & \\
\hline
\end{tabular}

(see Appendix A for full description)

The study looks at 55 unique products. 19 products are specifically intended for citizens, 12 specifically for businesses; another 12 products overlap and concern both citizens and businesses. Finally, the municipalities receive an overall e-maturity rating and a separate rating for citizens and businesses. These aggregate ratings are an averaging of all products assessed.

\section{Analysing the current state of e-maturity}

We assessed the e-maturity levels for a period covering three successive years, covering the period from 2014-2016. ${ }^{\text {ii }}$ The dataset which includes e-maturity data for the municipal products covers all Dutch municipalities, of which there were approximately 400. Over time, the researchers made some small measurement adjustments to their assessment. ${ }^{\text {iii }}$ As we are primarily interested in service delivery towards citizens, we restrict our use to the data about citizenoriented products of municipalities. A total of 31 products were used for our analysis.

Plotted for the three separate years, we see an upwards movement toward a greater average ematurity of municipalities (see Figure 1 and Table 2): with a mean of 57.5\% in 2014 and 59.3\% in 2015, moving further to a mean of $67.7 \%$ in 2016. The leap from 2015 to 2016 is in accordance with the initial ICT goals set by the minister for the municipal services. However, the variance between municipalities remains considerable, with municipalities scoring as high as $91.8 \%$ and as low as $29.7 \%$ in the same year, and the absence of significant differences in standard deviation per year suggests that this variance is of a lasting nature. In the next part we will assess possible explanations and determinants for this large degree of variance.

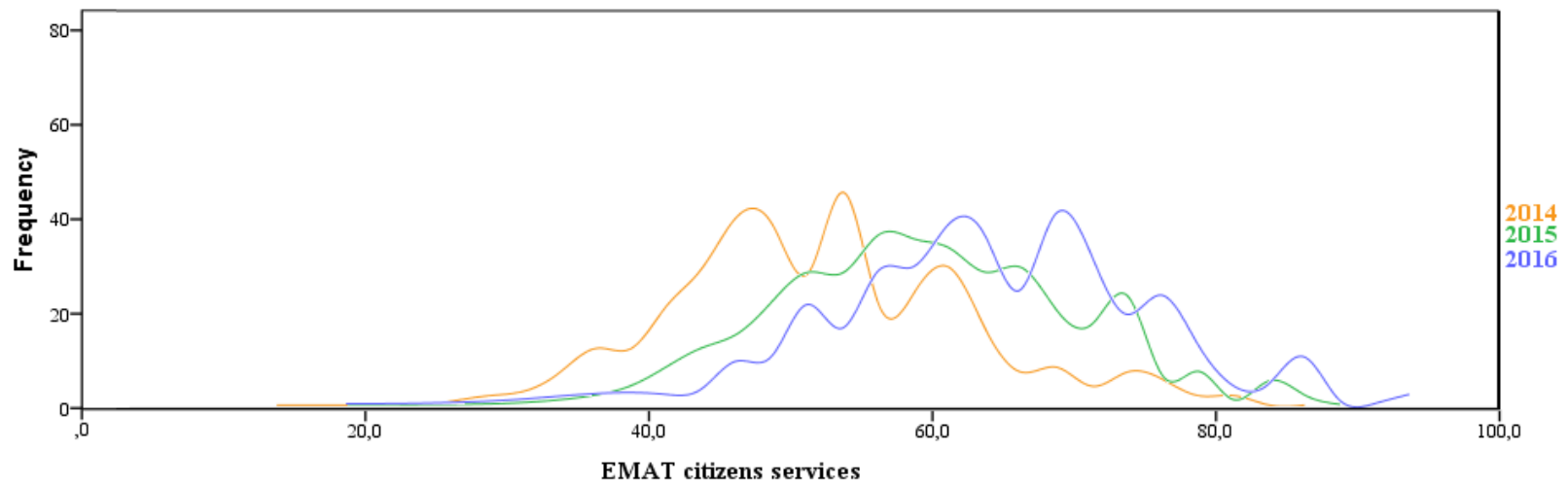

Figure 1. Density curves of e-maturity services for citizens in 2014, 2015 and 2016 
Table 2. Descriptive statistics e-maturity services for citizens

\begin{tabular}{cccccl}
\hline Year & N & Mean & St.Dev. & Min. & Max. \\
\hline 2014 & 391 & 51.5 & 11.0 & 13.6 & 86.9 \\
2015 & 393 & 59.3 & 11.1 & 19.6 & 88.0 \\
2016 & 389 & 64.6 & 10.8 & 19.6 & 94.0
\end{tabular}

\section{Determinants and hypotheses}

We used the aforementioned datasets on e-maturity as a basis for our analysis of the relationship between e-maturity and a selection of demographic and socio-economic factors. We mainly build on Manoharan's (2013) assessment of determinants for e-government adoption, in the context of American counties. We reviewed a selection of factors that are most interesting for e-maturity in the Dutch context. For every variable an applicable hypothesis is constructed.

The first variable we assess is population. One is inclined to expect that the larger the municipality is, the more opportunities and expertise there would be available to invest. There is a longstanding tradition that assumes the existence of a connection between organisation size and its capacity to innovate (see e.g. Rogers 1983): it forms an indicator of an array of underlying assumptions that stimulate innovation, such as total resources, technical expertise, and organisational structure. Prior research (Ho 2002; Andrews and Boyne 2009; Ruano de la Fuente 2014) points in the same direction: the larger the municipality, the greater the odds that it had more advanced forms of e-government.

Hypothesis 1: A municipality with a larger population will have a higher e-maturity level than a municipality with a smaller population.

Prior research also suggested that land area and population density have links with e-maturity (Ruano de la Fuente 2014), both variables form an indicator for organisational size. Manoharan (2013) writes that local governments that cover a large land area and are densely populated would be involved in such complex nature that they "would be already accounted for in the initial stages of e-government implementation" (163). As most municipalities in the Netherlands are relatively small in comparison with Manoharan's (2013) context of counties in the United States, and because of possible multicollinearity issues ${ }^{\text {iv }}$, we only include population density in our study.

Hypothesis 2: A municipality with a larger population density will have a higher e-maturity level than a municipality with a smaller population density.

In the literature, the demographic variable in relation to e-government adoption has been discussed frequently. Manoharan (2013) employs the age variable in a limited fashion, only reflecting on the mean age of counties; therefore we consulted other literature. The widely shared consensus here is that people with a more advanced age are less involved digitally, and thus lower the need for local e-government adoption (Ruano de la Fuente 2014; Colesca 2009; Gil-Garcia, Helbig, and Ferro 2006). Van Deursen and Van Dijk (2009) also observed that age was a significant predictor for measuring the level of operational ICT skills: a person of a more advanced age (specified as aged 55-80) would score significantly less on a test of operational ICT skills than a peer of a younger age (aged 18-29). For the latter it should be noticed that the presence of ICT- 
skills does not form an indicator in itself for more developed e-government, but it could nonetheless form an important precursor and incentive for a municipality to offer as much of its services digitally. In addition we argue that it is primarily the working people that would potentially benefit from e-government adoption, as they might have less time to visit the municipal hall during office hours. Finally, the youngest age group - aged 20 and younger - would be less inclined to make use of the products municipalities have on offer, e.g. because they are too young to consume their services.

Hypothesis 3a: A more extensive presence of people from the youngest age group forms a negative stimulus for e-maturity.

Hypothesis 3b: A more extensive presence of people from an older age group forms a negative stimulus for e-maturity.

Income per capita is another factor that is sometimes identified with innovative e-government on a national level (Siau and Long 2006). Manoharan (2013) also remarks that income level sets a level of expectation for local government in developing their ICT-facilities. He furthermore notes that the same can be discerned for education: counties with websites have a slightly higher percentage of high school graduates than counties without websites. For Van Deursen and Van Dijk (2009), who make four different classifications for their measurement of digital skills - operational, formal, information and strategic skills -, education level appears to be the only constant determining factor. Again it should be remarked that there is no self-evident causality between the presence of digital skills and the actual usage of e-government services.

Hypothesis 4: A municipality whose residents have a higher level of education will have more advanced e-maturity than a municipality whose residents have lower levels of education.

Hypothesis 5: A municipality whose residents have a higher income level will have more advanced e-maturity than a municipality whose residents have lower levels of income.

Finally we looked at the effect of municipal mergers on e-government adoption. In the Netherlands mergers take place every year, which makes it possible to retrace its eventual influences on other factors. ${ }^{\mathrm{v}}$ This provides an outlook for a closer view into the relation between e-government adoption and municipal mergers. In the literature on local government mergers, the act of municipal amalgamation is most often aimed at exploiting economies of scale (Blom-Hansen, Houlberg, and Serritzlew 2014; Allers and Geertsema 2016). Additionally it could be argued that a merger enables the newly formed municipality to restructure its operations, offering a chance to revise business processes (Homburg et al. 2014): e-government adoption and implementation could be a part of such a revision, in order to stimulate efficiency.

Hypothesis 6: A municipality that has been subject to a merger in the foregoing five years will have more advanced e-maturity than a municipality not subject to a recent merger.

Up to date, the relation between ICT developments and service delivery costs in local government has not been researched before to our best knowledge. In our setting, we think that there are both arguments for and against cost reductions because of the implementation of e-government. One the one hand, the adoption of e-government can be presented under the denominator of cost reduction (see e.g. Moon 2002): when for example products are directly accessible through a 
portal, the municipality is not inclined to appeal to its human resources to arrange a physical appointment. On the other hand, we expect that the implementation of e-government requires a certain amount of cost investments. These elements could work in opposite directions, leading to the absence of an aggregate effect. Therefore we formulate our last hypothesis as follows:

Hypothesis 7: There is no relation between e-maturity and the costs of services.

\section{Determinants of E-maturity}

In sum we looked for the relation between e-maturity and the following variables ${ }^{\mathrm{vi}}$ :

1. Population,

2. Population density,

3. Several age groups,

4. Percentage of working people with at least bachelor education,

5. Income per capita,

6. Subject to a recent merger

Four out of these six variables were included as continuous variables, and two as dummy variables. Statistics Netherlands developed a measure to determine the urbanisation degree of a municipality. This measure is divided into five categories that make a division in address density per $\mathrm{km}^{2}$. We included the first three categories as a dummy variable in our model as a means for population density, hereby taking the other two categories as the reference group ${ }^{\text {vii }}$. Finally, we also included a dummy variable for mergers. This assesses whether a municipality has been subject to a merger in the previous five years (counted from the year of observation) - some time delay should be accounted for, before its possible effects can be retraced. 'Income per capita' is the only variable for which data were available for just one year (2014). The differences in amount of observations per variable are due to missing or obviously erroneous values. Table 3 displays the descriptive statistics for all variables.

Table 3. Descriptive statistics for e-maturity, demographic and socioeconomic factors in the period 2014-2016

\begin{tabular}{|c|c|c|c|c|c|c|}
\hline & Abbr. & $\mathrm{N}$ & Mean & $\begin{array}{c}\text { St. } \\
\text { Dev. }\end{array}$ & Min & $\operatorname{Max}$ \\
\hline Population & POP & 1,174 & 43,135 & 67,033 & 926 & 848,687 \\
\hline $\begin{array}{l}\text { Population density category } 1(2,500+\text { address- } \\
\text { es per } \mathrm{km}^{2} \text {, dummy) }\end{array}$ & DENS1 & 1,176 & 0.04 & 0.20 & 0 & 1 \\
\hline Population density category $2(1,500-2,500)$ & DENS2 & 1,176 & 0.17 & 0.38 & 0 & 1 \\
\hline Population density category $3(1,000-1,500)$ & DENS3 & 1,176 & 0.21 & 0.41 & 0 & 1 \\
\hline Population density category 4 (less than 1,000 ) & DENS4 & 1,176 & 0.57 & 0.50 & 0 & 1 \\
\hline Percentage of people less than 20 years old & AGE-20 & 1,169 & 34.27 & 16.29 & 15 & 69 \\
\hline Percentage of people older than 65 & AGE65+ & 1,169 & 19.53 & 3.09 & 9 & 31 \\
\hline $\begin{array}{l}\text { Percentage of working people with at least a } \\
\text { bachelor education }\end{array}$ & EDU & 1,163 & 23.93 & 7.14 & 8 & 54 \\
\hline Income per capita in $€ 1000$ (2014 only) & INC & 388 & 15.21 & 1.51 & 11.04 & 22.69 \\
\hline Subject to a recent merger (dummy) & MERG & 1,176 & 0.04 & 0.21 & 0 & 1 \\
\hline
\end{tabular}


Dutch municipalities are considerably variable in size: their population numbers range from less than 1,000 to more than 800,000 inhabitants. The effects of this substantial variation in size are also reflected in some variables (population, land area, and income per capita). In line with Manoharan (2013) these variables were converted to their natural log form in order to reduce their skewness level.

As a next step we ran Spearman correlations of e-maturity with the natural logs of the demographic and socioeconomic factors, to get a rough indication of the centres of gravity of our model, and forestall possible issues and conflicts. ${ }^{\text {vii }}$ Table 4 gives an overview of the variables. As data for the income variable were only available for 2014, correlations for this variable were ran only with the 2014 data for all other variables $(\mathrm{N}=388)$.

Table 4. Correlations (Spearman) of e-maturity and socioeconomic factors

\begin{tabular}{|c|c|c|c|c|c|c|c|c|c|c|c|}
\hline & EMAT & POP & DENS1 & DENS2 & DENS3 & DENS4 & AGE-20 & AGE65+ & EDU & INC & MERG \\
\hline EMAT & 1 & & & & & & & & & & \\
\hline POP & $0.514 * *$ & 1 & & & & & & & & & \\
\hline DENS1 & $0.269 * *$ & $0.311 * *$ & 1 & & & & & & & & \\
\hline DENS2 & $0.239 * *$ & $0.429 * *$ & $-0.097 * *$ & 1 & & & & & & & \\
\hline DENS3 & $0.076 * *$ & $0.136 * *$ & $-0.109 * *$ & $-0.237 * *$ & 1 & & & & & & \\
\hline DENS4 & $-0.354 * *$ & $-0.571 * *$ & $-0.242 * *$ & $-0.527 * *$ & $-0.595 * *$ & 1 & & & & & \\
\hline AGE-20 & $-0.059 *$ & -0.010 & $-0.167 * *$ & -0.053 & $0.130 * *$ & 0.002 & 1 & & & & \\
\hline AGE65+ & $-0.173 * *$ & $-0.279 * *$ & $-0.183 * *$ & $-0.168 * *$ & $-0.075^{*}$ & $0.262 * *$ & $-0.595 * *$ & 1 & & & \\
\hline EDU & $0.133 * *$ & $-0.210^{* *}$ & $0.200^{* *}$ & $0.190 * *$ & $0.147 * *$ & $-0.349 * *$ & -0.026 & 0.020 & 1 & & \\
\hline INC & 0.013 & -0.035 & 0.004 & 0.093 & 0.081 & $-0.138 * *$ & $-0.103 *$ & $0.181 * *$ & $0.479 * *$ & 1 & \\
\hline MERG & $0.117 * *$ & $0.220 * *$ & -0.045 & 0.043 & 0.010 & -0.039 & 0.031 & -0.053 & 0.029 & 0.015 & 1 \\
\hline
\end{tabular}

The correlations already provide some starting points for interpretation. Apart from income, all demographic and socioeconomic variables have a relationship with e-maturity at the 0.01 level. Furthermore, apart from the fourth density category and the two age categories, all variables have a positive relationship. This significance already foreshadows a relationship between ematurity and demographic variables that were developed in our hypotheses and confirmed by earlier literature. Finally, there were no indications for multicollinearity in case we move on to regression analysis.

In order to further evaluate the relationship between municipal e-maturity and the demographic as well as socioeconomic factors, ordinary least squares regressions were used. Table 4 represents the results of four different models, broken down for 2014, 2015, 2016, and the pooled dataset of the three years combined. For the pooled regression, 2015 and 2016 dummies were added in order to enhance reliability of the outcomes. 
Table 5. Ordinary least squares regression analysis of demographic and socioeconomic determinants of e-maturity

\begin{tabular}{|c|c|c|c|c|}
\hline & $\begin{array}{r}\mathbf{2 0 1 4} \\
(\mathrm{N}=386)\end{array}$ & $\begin{array}{r}2015 \\
(N=381)\end{array}$ & $\begin{array}{r}2016 \\
(N=378)\end{array}$ & $\begin{array}{r}\text { Pooled } \\
(\mathrm{N}=1140)\end{array}$ \\
\hline (Const.) & 14.334 & 14.850 & 19.872 & 9.053 \\
\hline POP & $0.437 * * *$ & $0.449 * * *$ & $0.470 * * *$ & $0.405 * * *$ \\
\hline DENS1 & $0.140 * * *$ & $0.131 * *$ & $0.097 *$ & $0.110 * * *$ \\
\hline DENS2 & 0.054 & 0.064 & 0.072 & $0.057 *$ \\
\hline DENS3 & $0.096^{* *}$ & $0.083^{*}$ & $0.107 * *$ & $0.082 * * *$ \\
\hline AGE-20 & $-0.104 *$ & -0.085 & $-0.110 *$ & $-0.086^{*}$ \\
\hline AGE65+ & $-0.189 * * *$ & $-0.140 * *$ & $-0.115^{*}$ & $-0.133 *$ \\
\hline EDU & -0.035 & -0.019 & -0.054 & -0.03 \\
\hline INC & 0.021 & & & \\
\hline MERG & 0.004 & $0.088 * *$ & 0.048 & 0.054 \\
\hline Dummy 2015 & & & & $0.308^{*}$ \\
\hline Dummy 2016 & & & & $0.511 *$ \\
\hline $\mathbf{F}$ & 27.925 & 30.524 & 27.512 & 116.642 \\
\hline Adj. $R^{2}$ & $0.400 * * *$ & $0.391 * * *$ & $0.371 * * *$ & $0.503 * * *$ \\
\hline
\end{tabular}

Table 5 shows that all models are statistically significant and that the models for the three years investigated reveal rather similar results. Furthermore, the 2015 and 2016 dummies in the pooled regression confirm the aforementioned upward trend in the mean e-maturity. In line with earlier literature, population shows the highest and most consistent significance in three years and in the pooled estimation, and therefore supports Hypothesis 1 indicating that larger municipalities have a higher degree of e-maturity. Secondly, the results for the density variables show that municipalities with a larger population density on average have a higher e-maturity level, hereby supporting Hypothesis 2. Note however that there are some differences between the categories we distinguished. ${ }^{\text {ix }}$ The effect of age for both the younger and the older age group is negatively significant for almost all years. These findings support Hypotheses $3 \mathrm{~b}$ and - to a weaker extent 3a. Education and income level show no significance, and exert no or negligible influence on municipal e-maturity levels. Hypotheses 4 and 5 are therefore rejected. Finally, the effect of a municipal merger is significant for the 2015 and pooled models, but not for 2014 and 2016, so there are some, but no strong indications for Hypothesis 6.

\section{The relation between ICT and service delivery costs}

In this paragraph we present the relation between e-maturity and the costs of service delivery. In order to analyse this we analyse if there is a relation between three specific municipal cost items, or cost functions as they are called in the Netherlands, and the accompanying e-maturity for products assigned to that function. Data for these cost functions are publicly accessible for each municipality via the data portal of Statistics Netherlands (see Appendix B). For 2014 and 2015 we made use of the municipal financial reports. As these were not yet available for 2016, we used the budget figures for that year instead.

We compiled an additional e-maturity score by using the separate scores for a product with a direct relation with three specific municipal cost functions (see Appendix B). The three cost 
functions we assessed are the costs of general civil services (GCS), the costs for housing taxes (HT), and the costs for other municipal taxes (OMT). The choice for these three functions was made to explore the diversity of factors that might exert influence on the corresponding ematurity levels. Finally, for every municipality the cost items were converted to reflect the costs per inhabitant.

The costs of 'Housing taxes' and 'other municipal taxes' variables had to be trimmed, in order to reduce outliers, thereby reducing the number of observations. Table 6 shows that descriptive statistics of the resulting variables.

Table 6. Descriptive statistics (costs (€) per inhabitant) for 2014-16

\begin{tabular}{lllllllllllllllll}
\hline \multicolumn{4}{l}{ GCS } & \multicolumn{1}{c}{ HT } & \multicolumn{11}{c}{ OMT } \\
& N & Min & max & mean & st.dev & N & min & max & mean & st.dev & N & min & max & mean & st.dev \\
\hline $\mathbf{2 0 1 4}$ & 382 & 2.10 & 84.12 & 40.55 & 15.65 & 326 & 0.03 & 26.68 & 11.12 & 5.86 & 364 & 0.05 & 29.01 & 8.48 & 6.11 \\
$\mathbf{2 0 1 5}$ & 381 & 2.09 & 83.09 & 40.41 & 15.67 & 325 & 0.03 & 26.72 & 11.06 & 5.85 & 363 & 0.05 & 28.94 & 8.46 & 6.08 \\
$\mathbf{2 0 1 6}$ & 380 & 0.24 & 80.92 & 37.27 & 17.38 & 316 & 0.07 & 26.17 & 10.29 & 5.88 & 360 & 0.09 & 25.62 & 7.64 & 5.75 \\
\hline
\end{tabular}

For ally years, we ran correlations with the cost functions (per inhabitant) and e-maturity for the accompanying product, in order to look if e-maturity would be indicative for the costs. Due to the fact that the initial report uses a non-continuous scale for every separate product, we adapted dummies for the separate possible scores.

Our analyses revealed that none of the correlations turned out to be significant. This finding is in full support of Hypothesis 7. Again it should be mentioned that this does not mean that an effect is absent, but that for both directions an argument can be made for the relation between ematurity and the municipal cost functions.

\section{Conclusion and discussion}

In this article we sought different explanations for the variance in e-government adoption in Dutch municipalities. Population, population density, people of older age (65 and older) and to a lesser extent a greater presence of both merger and younger age (younger than 20) proved to be key predictors, confirming the findings in earlier literature on this subject. In contrast to findings from previous studies, income level and level of education did not significantly influence the level of e-maturity. This suggests that the level of e-government in the Dutch context is primarily driven by demographic and not so much by socio-economic characteristics.

Secondly we looked if e-maturity was to some extent related to cost items. Our analyses do not give indications that such a relationship exists. This was in accordance to our prior as there were opposing trends. Nevertheless, more research is needed to confirm our findings regarding the relation between e-maturity and cost items. This would be possible by adapting a more longitudinal design.

In addition, one could also ask not so much if the costs for the municipality would either rise or drop, as well as the costs for the end user: the citizen. This different approach to municipal costs could then be quantified by looking at the price of municipal products, such as passport and municipal permits. It must be noted, however, that such an approach has three limitations. First, some tariffs (e.g., for driver licences and passports) are maximized by central government. Second, municipalities can only charge citizens and businesses tariffs up to full costs of specific ser- 
vices, and are not allowed to make a profit. However, they are not obliged to cover the full costs, so they may under-price their services (Groot and Budding 2014). Third, in daily practice, municipalities use information on tariffs from neighbouring and other peer-municipalities to a large extent to determine their tariffs, hereby releasing the link between allocated costs and tariffs (Groot and Budding 2014).

Our definition of e-government adoption as 'e-maturity' is just one of few options of how the degree to which ICT is being used by municipalities could be operationalised. The literature gives clues for other indicators that measure e-government adoption or, less narrow, attention for ICT developments. In Spain, the Dossier of E-government Indicators (IRIA) gets published every two years by the High Council of Electronic Administration. According to the Dossier a steady and positive trend can be discerned towards greater investment in material and human resources related to ICT (Ruano de la Fuente 2014). Statistics Netherlands does not quantify ICT-costs separately, which also leads to more difficulties to isolate the possible effects. However, with the increasing importance of e-government and growing requirements for local government on the plane of ICT implementation the collection of data such as these in the Netherlands would not come as a surprise. Furthermore, for the American context Manoharan (2013) as well as Carrizales (2008) found that local governments with a separate IT department, or at least an appointed IT deputy, would pay significantly more attention to e-government than those with no IT department. Data for this for the Dutch context is not available, but the decisive importance they have in the American context indicate that this might be of importance for the Dutch context as well.

Another option for future research would be to analyse the relation between e-government adoption and government performance: would a higher e-maturity rate influence effectiveness, either as perceived by citizens or by means of performance indicators? The data available for government performance are still scarce and not comprehensive, but when these data are offered more extensively in the future, this could provide an interesting starting point for research.

Finally, it should be noted that the view of e-government adoption as e-maturity only represents one side of the coin, as it does not take into account possible risk factors and downsides to ICT adoption by local governments (see e.g. Netherlands Scientific Council for Government Policy 2011). Therefore a strict technocratic and context-free approach to the broader issue of ICT implementations is not recommended.

\section{References}

Allers, M.A. and J.B. Geertsema. 2016. "The Effects of Local Government Amalgamation on Public Spending, Taxation, and Service Levels: Evidence from 15 Years of Municipal Consolidation.” Journal of Regional Science, 56 (4): 659-682. Doi: 10.1111/jors.12268/suppinfo.

Andersen, K. V. and H.Z. Henriksen. 2006. "e-Government maturity models: Extension of the Layne and Lee model." Government Information Quarterly, 23 (2): 236-248. doi: 10.1016/j.giq.2005.11.008.

Andrews, R. and G. Boyne. 2009. "Size, structure and administrative overheads: an empirical analysis of English local authorities." Urban Studies 16 (4): 739-759. Doi: 10.1177/0042098009102127.

Bel, G., Fageda, X., Dijkgraaf E., and R.H.J.M. Gradus. 2010. "Similar problems, different solutions: comparing refuse collection in the Netherlands and Spain." Public Administration 88 (2): 479-496. doi: 10.1111/padm.2010.88.issue-2. 
Blom-Hansen, J., Houlberg, K., and S. Serritzlew. 2014. "Size Democracy, and the Economic Costs of Running the Political System." American Journal of Political Science 56 (4): 790-803. Doi: 10.1111/ajps.12096.

Carrizales, T. 2008. "Functions of e-government: A study of municipal practices." State and Local Government Review, 40 (1): 12-26. Doi: 10.1177/0160323X0804000102.

Carter, L. and F. Belanger. 2005. "The utilization of e-government services: Citizen trust, innovation and Acceptance.” Information Systems Journal 15: 5-25. Doi: 10.1111/j.1365-2575.2005.00183.x.

Deloitte, 2015. Meting aanbod Digitale Dienstverlening 2014. Final Report, commissioned by Ministry of the Interior and Kingdom Relations and the Ministry of Economic Affairs.

Deloitte, 2016. Meting aanbod Digitale Dienstverlening 2015. Final Report, commissioned by Ministry of the Interior and Kingdom Relations and the Ministry of Economic Affairs.

Deloitte, 2017. Meting aanbod Digitale Dienstverlening 2016. Final Report, commissioned by Ministry of the Interior and Kingdom Relations and the Ministry of Economic Affairs.

Van Deursen, A.J.A.M., and J.A.G.M. van Dijk. 2009. "Improving digital skills for the use of online public information and services." Government Information Quarterly 26 (2): 333-340. Doi: 10.1016/j.giq.2008.11.002.

Dunleavy, P., Margetts, H., Bastow, S., and J. Tinkler. 2005. New Public Management Is Dead-Long Live Digital-Era Governance. Journal of Public Administration Research and Theory, 16 467-494. Doi: 10.1093/jopart/mui057.

Ernst and Young. 2013. Benchmark digitale dienstverlening. Final Report.

European Commission. 2017. Digital Economy and Society Index 2017. Press release, Brussels, 3 March.

European Union. 2012a. Digital Agenda for Europe, individuals interaction online with public authorities 2012.

European Union. 2012b. Digital Agenda for Europe, individuals interaction online with public authorities 2011 vs 2012.

Gil-Garcia, J.R., Helbig, N.C., and E. Ferro. 2006. "Is It Only About Internet Access? An Empirical Test of a Multi-dimensional Digital Divide." In: Wimmer, M.A., Scholl, H.J., Grönlund, Å., and K.V. Andersen. (eds.) Electronic Government. EGOV 2006. Lecture Notes in Computer Science, 4084. Berlin / Heidelberg: Springer.

Gottschalk, P., 2009. "Maturity levels for interoperability in digital government." Government Information Quarterly 26 (1): 75-81. Doi: 10.1016/j.giq.2008.03.003.

Groot, T.L.C.M. and G.T. Budding. 2004. "The influence of New Public Management practices on product costing and service pricing decisions in Dutch municipalities." Financial Accountability \& Management 20 (4): 421-443. Doi: 10.1111/j.1468-0408.2004.00202.x.

Ho, A.T. 2002. "Reinventing Local Governments and the E-Government Initiative. Public Administration Review" 62 (4): 434-444. Doi: 10.1111/00333352.00197.

Homburg, V., Dijkshoorn, A., and M. Thaens. 2014. "Diffusion of Personalised Services among Dutch Municipalities: Evolving Channels of Persuasion." Local Government Studies 40 (3): 429-450. Doi: 10.1080/03003930.2013.795892.

Interior Ministry (Ministerie van Buitenlandse Zaken). 2013. Visiebrief digitale overheid 2017. Ministry of the Interior and Kingdom Relations, Reference 2013-0000306907.

Layne, K. and J. Lee. 2001. "Developing fully functional E-government: A four stage model." Government Information Quarterly 18 (2): 122-136.

Manoharan, A. 2013. "A Study of the Determinants of County E-Government in the United States." American Review of Public Administration 43 (2): 159-178. Doi: 10.1177/0275074012437876.

Moon, M.J. 2002. "The Evolution of E-Government among Municipalities: Rhetoric or Reality?" Public Administration Review 62 (4): 424-433. Doi: 10.1111/0033-3352.00196.

Nasi, G., Frosini, F., and D. Cristofoli. 2011. Online service provision: are municipalities really innovative? The case of larger municipalities in Italy. Public Administration 89 (3): 821-839. Doi: 10.1111/j.1467-9299.2010.01865.x. 
Netherlands Scientific Council for Government Policy (Wetenschappelijke Raad voor Regeringsbeleid). 2011. iOverheid. WRR-Rapport 86.

Pollitt, C. 2003. Joined-Up government. A Survey. Political Studies Review, 1 (1): 34-49. Doi: 10.1111/1478-9299.00004.

Rogers, E.M. 1983. Diffusion of innovations. London: Collier Macmillan.

Ruano de la Fuente, J., 2014. E-Government Strategies in Spanish Local Governments. Local Government Studies 40(4): 600-620. Doi: 10.1080/03003930.2013.787414.

Siau, K. and Y. Long. 2006. Using social development lenses to understand e-government development. Journal of Global Information Management 14 (1): 47-61. Doi: 10.4018/jgim.2006010103.

Statistics Netherlands (Centraal Bureau voor de Statistiek). 2012. ICT, Kennis en economie. Report, Den Haag/Heerlen.

Statistics Netherlands (Centraal Bureau voor de Statistiek). 2016. Aantal gemeenten in 2016 daalt naar 390. Online: https://www.cbs.nl/nl-nl/nieuws/2016/01/aantal-gemeenten-in-2016-daalt-naar-390, last accessed 20 april 2017.

Valdés, G., Solar, M., Astudillo, H., Iribarren, M., Concha, G., and M. Visconti, M. 2011. "Conception, development and implementation of an e-Government maturity model in public agencies." Government Information Quarterly 28 (2): 176-187. Doi: 10.1016/j.giq.2010.04.007.

Yildiz, M. 2007. E-government research: Reviewing the literature, limitations, and ways forward. Government Information Quarterly, 24 (3): 646-665. Doi: 10.1016/j.giq.2007.01.002 


\section{Appendix A: E-maturity scale}

The Deloitte e-maturity survey measures the digital maturity level of the most used products for citizens and businesses in municipalities. For the scale for this e-maturity level, the following classification is used.

\begin{tabular}{ll}
\hline Maturity level & Description \\
\hline 1. Not digital, only information (0\%) & $\begin{array}{l}\text { The application (form) is not digitally available, } \\
\text { and the website only offers information about the } \\
\text { product. }\end{array}$ \\
$\begin{array}{ll}\text { 2. Digital download but requires printing (fill out } \\
\text { manually) (33\%) } \\
\text { use of a printer to process the request (e.g. for sign- } \\
\text { ing the application). } \\
\text { 3. Digital download, fill out and send back (66\%) }\end{array}$ \\
$\begin{array}{l}\text { Opportunity to digitally submit the application, e.g. } \\
\text { through a web form, not requiring the use of a } \\
\text { printer. } \\
\text { The website provides the opportunity to use a } \\
\text { completed form and to digitally send/upload it. }\end{array}$ \\
\hline Product not perceived
\end{tabular}

The following table presents a list of products compiled by Deloitte, that most municipalities offer to citizens. For each product the survey made an assessment of its maturity level.

Products for citizens

\begin{tabular}{|c|c|c|}
\hline G01 & $\begin{array}{l}\text { Make an appointment } \\
\text { for passport application }\end{array}$ & $\begin{array}{l}\text { Government organisations offer the opportunity to schedule an ap- } \\
\text { pointment for a passport. For a passport, face-to-face verification is } \\
\text { necessary, so a citizen must always go to a desk physically, but mak- } \\
\text { ing an appointment could take place digitally. }\end{array}$ \\
\hline G02 & g within munici- & $\begin{array}{l}\text { When a person is moving within his / her municipality, this must be } \\
\text { passed on. }\end{array}$ \\
\hline G03 & $\begin{array}{l}\text { sion } \\
\text { lodging }\end{array}$ & $\begin{array}{l}\text { If a person resides with someone else, a senior person of that address, } \\
\text { or the owner, must declare that the person is resident at the address } \\
\text { and may be enrolled. }\end{array}$ \\
\hline G05 & $\begin{array}{l}\text { Publi } \\
\text { tion }\end{array}$ & $\begin{array}{l}\text { The public space is a collective name for the places that citizens use. } \\
\text { Such as squares, roads, sports fields and parks. Is there anything in } \\
\text { public space not alright? Then a notice can be made public space at } \\
\text { the municipality. }\end{array}$ \\
\hline G06 & $\begin{array}{l}\text { Exce } \\
\text { Regi } \\
(B R\end{array}$ & $\begin{array}{l}\text { partner and child data, and shows that a person } 1 \\
\text { municipality. One can only obtain an BRP extra } \\
\text { pality where one is currently enrolled. }\end{array}$ \\
\hline G07 & Request copy / excerpt & The municipality stores deeds of life events. For example, a birth, \\
\hline \multicolumn{3}{|c|}{$\begin{array}{l}\text { an identity management platform which government agencies of the Netherlands can use to verify the } \\
\text { nutch residents on the Internet. } \\
\text { ly online. } \\
\text { ly ormation about the product is available for example, because the product does not exist or it is stated that } \\
\text { ct is not applicable for the organisation (for example, deregulation). Observations that fall into this catego- } \\
\text { count in the calculations of the averages. }\end{array}$} \\
\hline
\end{tabular}


birth certificate (excerpt marriage, registered partnership, divorce or death. A citizen may recivil registry) quest a copy or extract of these deeds from the municipality. An extract of marital status is a collective name for these deeds. Here it is specifically about a birth certificate.

$\begin{array}{ll}\text { G08 } & \begin{array}{l}\text { Appointment bulky } \\ \text { waste }\end{array} \\ \text { G09 } & \text { Waste, calendar (digital } \\ \text { access or request) }\end{array}$

G10 Request waste container

G11 Arrange intended mar-
riage

G13 Lost or found objects

G14 Request compensation for school transport

G15 Change name usage

G16

Request assistance benefit

G17 Register dog (dog tax)

Request property tax

G18 remission (municipal $\operatorname{tax})$
Bulky waste is waste that is too big and too heavy to offer in a garbage bag or container.

The waste pointer provides more information about the fixed collection days of the waste.

This concerns the application of a waste container for collecting and collecting regular household waste from citizens (usually linked to a residential address).

If a couple wants to marry or register a registered partnership, they must be notified in advance to the municipality. This is called 'ondertrouw'.

The municipality has taken over the handling of found and lost objects from the police.

Student transport is a full or partial reimbursement of transportation costs to and from school. Whether a citizen qualifies for this depends on a number of things.

A person can use his partner's last name. This can be if the person is married or if the person is a registered partner. The person's own gender name does not change, just the name with which the person is attributed.

When a person has insufficient money to provide his/her living, (s)he will be eligible for an allowance benefit.

For each dog that owns a person, the person pays an annual tax to the municipality.

When a person cannot pay the municipal tax, the person can ask the municipality for remission.

Products for both citizens and businesses

When a citizen or business is not satisfied with the services of the

G19 /

G20

File complaint

G21 /

G22

G23 / Request parking permit

G24 for visitors

G27

Request certificate of good conduct

G29 /

G30

Use of public street

G31 /

G32 municipality. Then (s)he can file a complaint. For example, a person may have a complaint about the way in which the municipality performs its duties. Also, the submission of a customer may concern how (s)he has been treated by a local employee.

A parking permit is a permit that allows you to park in places where others in similar circumstances may not.

With a visitor license, the person can let his visitor be free or discounted.

The certificate of good conduct (Verklaring Omtrent Gedrag, VOG) is a statement that one's behavior does not provide impediments for a new job. A VOG is required for teachers and taxi drivers, for example. Employers for whom you are going to work with confidential data or money can also ask for a VOG.

When a citizen or business wants to temporarily place a container, scaffold or other object on public road or hang out a banner or party lighting, (s)he must apply for a permit.

This is a contact form for general questions or comments to the municipality. 


\section{G35 Request (small) event license \\ G37 / Request / view valua- \\ G38 tion report}

G39 / Request / view sewage

G40 disposal

G41 / File objection under the

G42 General Administrative Law Act (AWB)

G43 / Request direct debits for By authorizing the municipality, municipal tax assessment(s) can be G44
A license is required for the organising $f$ a small event.

The assessment report further substantiates the value of a house or property, in accordance with the Immovable Poperty Act (Wet Onroende Zaken, WOZ).

Sewage tax is a tax paid by every household and any company with a sewage connection. The yield of this tax is used for the maintenance of the municipal sewage system. In addition, the municipality uses the proceeds for the collection of rainwater and the approach to urban groundwater problems. Every year households and companies receive a municipal tax bill containing the sewage tax.

If you do not agree with a decision by a municipal administrative body (the mayor and councilor's mayor or councilor), within a few weeks after the announcement / dispatch of a decision, you may submit an objection to the administrative body that has the decision Taken. paid by automatic depreciation. 


\section{Appendix B: Costs}

All municipal cost categories for the Netherlands are published as open data on the website of the Netherlands Statistics. We picked out three of them. Accordingly, we linked some of the products that were assessed in the e-maturity survey to the costs to a specific kind of service delivery. The general civil services entry represents the aggregate e-maturity rating of a selection of municipal products; 'housing taxes' and 'other municipal taxes' represent the e-maturity of only one accompanying product. In the table below is the description of every cost function, and the municipal citizen products that were used for comparison for each cost function.

\begin{tabular}{|c|c|c|}
\hline Function & Description & $\begin{array}{l}\text { Connected to e-maturity } \\
\text { level of municipal prod- } \\
\text { ucts }\end{array}$ \\
\hline 003 General civil services & 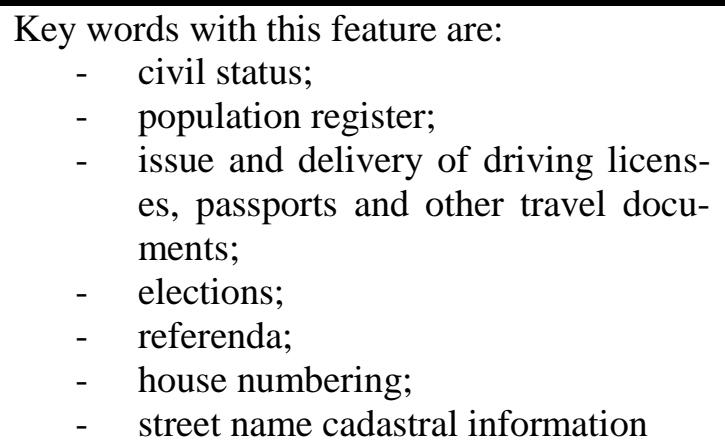 & $\begin{array}{l}\text { VOG; passport; Change } \\
\text { names; BRP; Moving with- } \\
\text { in municipalities; Moving, } \\
\text { permission for occupant }\end{array}$ \\
\hline 930 Housing taxes & $\begin{array}{l}\text { This function includes the income and ex- } \\
\text { penses that relate to the valuation of real } \\
\text { estate under the } \\
\text { Key concepts for this feature are: } \\
\text { - Law valuation of immovable proper- } \\
\text { ty; } \\
\text { - contributions to the central govern- } \\
\text { ment and water boards regarding the } \\
\text { municipal implementation of the } \\
\text { WOZ Act. }\end{array}$ & $\begin{array}{l}\text { Request / View Tax Report } \\
\text { WOZ }\end{array}$ \\
\hline 940 Other municipal taxes & $\begin{array}{l}\text { This function includes the income and ex- } \\
\text { penses that relate to the levying and collec- } \\
\text { tion of taxes mentioned under the functions } \\
931 \text { to } 939 \text {. This function also includes costs } \\
\text { relating to the handling of objections / ap- } \\
\text { peals and the costs incurred when appealed. }\end{array}$ & $\begin{array}{l}\text { Request direct debit for } \\
\text { paying municipal taxes }\end{array}$ \\
\hline
\end{tabular}




\section{Notes}

${ }^{\mathrm{i}}$ Meanwhile this end date has become more lenient, and the Vereniging van Nederlandse Gemeenten (Association of Dutch Municipalities) managed to negotiate 2020 as the final year in which municipal services should be offered in a digital portal.

ii Deloitte started its measurement in 2014; therefore the data for only three years are available for research at present. Between 2006 and 2013 a similar survey was conducted by Ernst and Young under the denominator of 'Benchmark Digital Service Delivery'; however, the design of this benchmark is fundamentally different from Deloitte's measurement, making it incompatible with the more recent data. Therefore we limit ourselves to the 2014-2016 time period.

iii In order to avoid differences in e-maturity measurement between years we used listwise removal for products that were not included in measurement of one or more years, so as to prevent distortion between the observations in the three years under consideration (See Appendix A for full disclosure).

${ }^{\text {iv }}$ As our variable for population density is defined as the address density per $\mathrm{km}^{2}$, we expect land area and population density to be highly correlated.

${ }^{\mathrm{v}}$ In the Netherlands, there were 625 municipalities in 1996, but by 2006 this number has fallen to 458 (Bel et al. 2010) and by 2016 to 390 (Statistics Netherlands 2016).

${ }^{\text {vi }}$ All socioeconomic variables are accessible as open data through the portal of Statistics Netherlands.

${ }^{\text {vii }}$ This reference group consists of municipalities with less than 1,000 addresses per $\mathrm{km}^{2}$. Note that Statistics Netherlands distinguishes two groups of 'rural areas': those with 500-1,000 addresses per $\mathrm{km}^{2}$ and those with less than 500 per $\mathrm{km}^{2}$. However, as we are primarily interested in the differences between urban and rural areas, we combined both rural groups.

viii We ran additional Pearson correlations for the relationship between continuous variables to look for significant differences, but results were comparable. Data are available upon request.

${ }^{\mathrm{ix}}$ Interestingly, the third density category $\left(1,000-1,500\right.$ addresses per $\left.\mathrm{km}^{2}\right)$ is also significant for all years and the pooled model, whereas the second category $\left(1,500-2,500\right.$ addresses per $\left.\mathrm{km}^{2}\right)$ is only significant for the pooled model. Thus medium-sized cities seem to perform better in their e-government adoption than cities in the slightly larger density category $\left(1,500-2,500\right.$ addresses per $\left.\mathrm{km}^{2}\right)$. An explanation for this is difficult to find, and not supported by earlier literature. 